\title{
Editorial: Linking Optical and Chemical Properties of Dissolved Organic Matter in Natural Waters
}

\author{
Christopher L. Osburn ${ }^{1 *}$ and Thomas S. Bianchi ${ }^{2}$ \\ ${ }^{1}$ Department of Marine, Earth, and Atmospheric Sciences, North Carolina State University, Raleigh, NC, USA, ${ }^{2}$ Department \\ of Geological Sciences, University of Florida, Gainesville, FL, USA
}

Keywords: CDOM, DOC, absorbance, fluorescence, biomarkers, stable isotopes, photochemistry

\section{Editorial on the Research Topic}

\section{Linking Optical and Chemical Properties of Dissolved Organic Matter in Natural Waters}

Dissolved organic matter (DOM) represents the largest reservoir of exchangeable reduced carbon in the ocean. The dynamics of this reservoir are partly due to riverine and coastal inputs but also due to primary production in the sea surface and export to depth (e.g., Bauer and Bianchi, 2011). Forming the basis of the microbial loop, DOM is an active and integral part of marine ecosystems and a critical component of the Earth's carbon cycle. The fraction of DOM that absorb light is termed chromophoric or colored DOM: CDOM. First described as "gelbstoff" or the yellow color in coastal waters, CDOM plays a key role in the ocean's carbon cycle through its absorption of sunlight, which results in an alteration of the underwater light field via contributing to light attenuation in the water column as well the potential for a variety of photochemical reactions to occur which can influence the redox chemistry of seawater and-via photooxidation-lead to the generation of carbon dioxide $\left(\mathrm{CO}_{2}\right)$ from DOM (Coble, 2007). The latter constitutes and important feedback loop for Earth's climate.

However, the light absorbing properties of CDOM also make it an important means of quantifying this pool of DOM. Ultraviolet-visible spectroscopy is used to quantify "amounts" of $\mathrm{CDOM}$ absorbance at specific wavelengths and the slope coefficient of models describing the absorption change with wavelength (spectral slopes or S values) inform on DOM quality (Stedmon and Markager, 2003; Helms et al., 2008). A fraction of CDOM emits light as fluorescence and fluorescence spectra often contain more structure hence more information. Multiple emission spectra measured at discrete wavelengths are concatenated into 3D excitation-emission matrices (EEMs), which for a sample may be easily visualized as a contour plot. In these plots certain classical peaks have been used to represent DOM sources and chemistry: A, C (terrestrial humic-like fluorescence), M (microbially-produced humic fluorescence), and $\mathrm{T}$ (protein-like fluorescence) (Coble, 1996, 2007). Uncertainty in the peak-selection technique lead to utilizing chemometrics to decompose arrays of EEMs into the underlying components via parallel factor analysis (PARAFAC) (Stedmon et al., 2003).

The global view of CDOM absorbance and fluorescence in the oceans was given by Nelson and Gauglitz. Distributions of classical EEM peaks show that intensities of humic-like fluorescence increase with depth in pelagic ocean. Correlations between apparent oxygen utilization (AOU), which increase with DOM mineralization, and EEM peaks were variable across major ocean basins with peak T exhibiting overall weakest correlations. Production of humic fluorescence in the deep ocean appeared to coincide with remineralization of particles in accordance with the microbial carbon pump hypothesis (Jiao et al., 2010). Thus, CDOM absorbance and fluorescence are tracers 
of active DOM cycling and have the potential to identify so-called labile, semi-labile, and refractory components (Hansell, 2013).

In major ocean basins of the Arctic, Guéguen et al. use PARAFAC components to separate mixing of water from the Makarov Basin, enriched in humic fluorescence, with water from the Canada basin depleted in such terrestrial DOM. Looking specifically at the Lena River plume and Laptev Sea, Gonçalves-Araujo et al. examined PARAFAC fluorescence results and concluded that hydrographic processes, controlled by river flow, influence the distributions of components, while photodegradation and flocculation exert secondary controls on DOM fate.

Indeed, observations from tidal rivers to the coastal ocean demonstrate very close correspondence between DOC and CDOM that is principally driven by export of terrestrial DOM into the ocean. A key example of this linkage is the high correlation between CDOM and DOC and, especially CDOM and the terrestrial biomarker lignin. Large river systems, especially in the Arctic, reflect these linkages most directly. Mann et al. demonstrate high correlations between DOC and CDOM absorption at $350 \mathrm{~nm}\left(\mathrm{a}_{350}\right)\left(R^{2}=0.81 ; N=301\right)$, with even higher correlations between dissolved lignin $\left(\Sigma_{8}\right)$ and $\mathrm{a}_{350}\left(R^{2}=0.93 ; N=31\right)$. Lignin composition was modeled with a combination of CDOM absorption coefficient and slope values. Developing this analysis in coastal shelves, Fichot et al. explore relationships between lignin reactivity and identify key lignin-phenol groups responsible for largest variability, but also note lignin is one of many terrestrial and planktonic sources of CDOM absorbance in natural waters. Establishing such high correlations are important because they allow CDOM, which can be measured with greater rapidity and ease, to estimate DOC concentrations and fluxes. For example, a highly linear relationship between lignin and $\mathrm{a}_{400}$ can be utilized with remote sensing models to measure lignin concentrations from space (Fichot et al.). Stubbins et al. extend the linkage beyond the lignin biomarkers to dissolved black carbon (DBC). Using highly correlated relationships between $\mathrm{a}_{254}$ and $\mathrm{DBC}$ concentration coupled with hydrologic model, they estimated that nearly $10 \%$ of Arctic DOC export could be in the form of DBC.

Fluorescence provides more information than absorbance about biochemical classes of DOM and hence its reactivity. In the Northern Gulf of Mexico, Yamashita et al. examined linkages between CDOM and lignin but also CDOM and total dissolved amino acids (TDAA) using PARAFAC components. Lignin was best correlated with terrestrial, fulvic-acid like fluorescence, while protein-like fluorescence, resembling tryptophan, was best correlated to TDAA.

Estuaries represent the terrestrial-aquatic interface in which variable riverine inputs, long residence times, and complex mixing dynamics complicate the strong linkage between DOM's optical and chemical properties. Biological and chemical processes may "overprint" clear terrestrial-marine gradients, continuously altering DOM's biogeochemical properties, and result in a continuum of optical properties associated with its changing chemistry expressed in lignin, but also in its elemental $(\mathrm{C}: \mathrm{N})$ and stable carbon isotope $\left(\delta^{13} \mathrm{C}\right)$ properties (Asmala et al.; Osburn et al.). Seasonal variation in riverine inputs to estuaries resulted in marked changes in regression models between optics and chemistry (Osburn et al.). In fact, CDOM performed better as a predictor of lignin concentration than of DOC in estuarine environments given the dynamics of continual supply, removal, and transformation of organic matter.

Underlying the linkages between observed optical and chemical properties of DOM across the terrestrial to marine continuum are sophisticated molecular level processes expressed at the macro level in measurements of CDOM light absorption, fluorescence, and geochemical markers. It is important that wet chemical techniques used to isolate biomarkers and/or to concentrate DOM for mass spectral analysis represent the whole of DOM. Andrew et al. examined optical properties of $\mathrm{C}_{18}$ extracts compared to whole waters and found a preferential selection of high molecular weight material. This was evidenced by lower spectral slope values. This effect was more pronounced for riverine waters and diminished offshore. Optical reactivity (quantum yields for fluorescence and wavelength dependence of fluorescence emission) indicated that this extraction procedure serves as a good representative of the whole water CDOM. Wünsch et al. make a considerable step forward in developing a PARAFAC-based model which allows users to explore the biochemical composition of DOM using fluorescence quantum yields.

Molecular size and weight variations in DOM appear to strongly influence its optical properties and attendant relationships to bulk chemical parameters (Asmala et al.). Reader et al. show the power of optical properties in explaining much of DOM's composition and reactivity when absorption spectra are linked to mass spectral data. Employing principle component analysis (PCA), results from coastal riverine DOM exhibited discrete absorbance spectral features statistically related to discrete molecular mass ranges. Further, DOM photoreactivity resulted in loss of absorbance clearly related to decreases molecular mass.

In the coastal Florida Everglades, Wagner et al. have undertaken study of DOM's optical properties and mass spectral properties using state-of-the-art Fourier-transform ion cyclotron resonance mass spectrometry (FT-ICR-MS) and linking this high resolution chemical information to PARAFAC fluorescence components. Across this terrestrial-marine interface comprised of riverine, wetland, and marine DOM sources, optics are confirmed to be appropriate proxies for DOM chemistry, as Spearman rank correlations of results were consistent with prior source assignments and elucidated rather complex mixing dynamics observed in estuarine environments. These results match well with black carbon being an important component of DOC export from rivers (Stubbins et al.).

Optical-chemical linkages in DOM's chemistry is manifestly expressed in its reactivity. Sun and Mopper conducted a processbased study of DOM leached from wood in a coastal wetland in which substantial flocculation of material was induced via addition of iron, which also increased production of hydroxyl radicals that lead to photooxidation of DOM. Thus DOM processing and degradation are inextricably linked to elemental cycles such as iron. Timko et al. further investigate the role of photodegradation in the open ocean as a producer 
of fluorescence signal and potential role in formation of recalcitrant DOM. Ultra-high resolution mass spectrometry was again employed to suggest that DOM molecules resistant to photodegradation are aliphatic in nature. Polyphenolic aromatic structures were prevalent in photoreactive deep waters, implicating their removal in surface waters during overturning circulation and also further indicating their formation via the microbial carbon pump.

Linkages between optics and chemistry of bathypelagic DOM which may be forged by the microbial carbon pump further emphasize our need to understand means by which deep ocean fluorescent, photoreactive material is formed. DOM's role in the microbial loop adds complexity to the linkages between optical and chemical properties of DOM in the surface ocean. Recent discoveries of base-extractable DOM from particulate organic matter (BEPOM) exhibits fluorescence patters consistent with biochemical sources from phytoplankton and bacterioplankton confirm autochthonous processes in shaping DOM's optical properties (Osburn et al., 2012; Nelson and Siegel, 2013; Brym et al., 2014). Aparicio et al. investigated the importance of the microbial degradation in leading to potential "recalcitrance" of DOM by exposing bathypelagic Atlantic Ocean bacteria to simple substrates (sugars, amino acids) and to humic acid. Fluorescence was generated most in treatments with humic precursors while protein-like fluorescence decreased most when fresh amino acids were added. This result suggests that

\section{REFERENCES}

Bauer, J., and Bianchi, T. S. (2011). "Dissolved organic carbon cycling and transformation," in Treatise on Estuarine and Coastal Science, Vol. 5, eds E. Wolanski and D. S. McLusky (Waltham: Academic Press), 7-67.

Brym, A., Paerl, H. W., Montgomery, M. T., Handsel, L. T., Ziervogel, K., and Osburn, C. L. (2014). Optical and chemical characterization of base-extracted particulate organic matter in coastal marine environments. Mar. Chem. 162, 96-113. doi: 10.1016/j.marchem.2014.03.006

Coble, P. G. (1996). Characterization of marine and terrestrial DOM in seawater using excitation-emission matrix spectroscopy. Mar. Chem. 51, 325-346. doi: 10.1016/0304-4203(95)00062-3

Coble, P. G. (2007). Marine optical biogeochemistry: the chemistry of ocean color. Chem. Rev. 107, 402-418. doi: 10.1021/cr050350+

Hansell, D. A. (2013). Recalcitrant dissolved organic carbon fractions. Ann. Rev. Mar. Sci. 5, 421-445. doi: 10.1146/annurev-marine-120710-100757

Helms, J. R., Stubbins, A., Ritchie, J. D., Minor, E. C., Kieber, D. J., and Mopper, K. (2008). Absorption spectral slopes and slope ratios as indicators of molecular weight, source, and photobleaching of chromophoric dissolved organic matter. Limnol. Oceanogr. 53, 955-969. doi: 10.4319/lo.2008.53.3.0955

Jiao, N., Herndl, G. J., Hansell, D. A., Benner, R., Kattner, G., Wilhelm, S. W., et al. (2010). Microbial production of recalcitrant dissolved organic matter: longterm carbon storage in the global ocean. Nat. Rev. Microbiol. 8, 593-599. doi: $10.1038 /$ nrmicro2386 marine humification processes indeed persist in the ocean and underlying mechanisms remain poorly known. Ziervogel et al. discovered in coastal waters of the Gulf of Mexico that, after Hurricane Isaac, close linkage between BEPOM fluorescence and bacterial activities, indicating how quality of organic matter in particle-rich environments is driving much of the bacterial activity. Nutrient regimes and the formation of flocculant particles ("marine snow") may be unrealized factors controlling formation of optically-active and recalcitrant DOM.

In summary, this research topic offers a globally-relevant picture of the linkage between optical and chemical properties of DOM, showing the many recent advancements in observations and techniques that will continue to improve our understanding of the organic carbon cycle. Using harmonized approaches linking optics and chemistry can provide a framework for understanding remaining knowledge gaps. These include the significant and still poorly understood biogeochemistry across the terrestrial-marine continuum that leads to export of reactive material onto coastal shelves, as well as the linkages between production of organic matter in surface waters and transformation into recalcitrant DOM fractions during transport to the bathypelagic ocean.

\section{AUTHOR CONTRIBUTIONS}

$\mathrm{CO}$ and TB both contributed to the writing of this editorial.

Nelson, N. B., and Siegel, D. A. (2013). The global distribution and dynamics of chromophoric dissolved organic matter. Annu. Rev. Mar. Sci. 5, 447-476. doi: 10.1146/annurev-marine-120710-100751

Osburn, C. L., Handsel, L. T., Mikan, M. P., Paerl, H. W., and Montgomery, M. T. (2012). Fluorescence tracking of dissolved and particulate organic matter quality in a river-dominated estuary. Environ. Sci. Technol. 46, 8628-8636. doi: $10.1021 /$ es 3007723

Stedmon, C. A., and Markager, S. (2003). Behaviour of the optical properties of coloured dissolved organic matter under conservative mixing. Estuar. Coastal Shelf Sci. 57, 973-979. doi: 10.1016/S0272-7714(03)00003-9

Stedmon, C. A., Markager, S., and Bro, R. (2003). Tracing dissolved organic matter in aquatic environments using a new approach to fluorescence spectroscopy. Mar. Chem. 82, 239-254. doi: 10.1016/S0304-4203(03)00072-0

Conflict of Interest Statement: The authors declare that the research was conducted in the absence of any commercial or financial relationships that could be construed as a potential conflict of interest.

Copyright (c) 2016 Osburn and Bianchi. This is an open-access article distributed under the terms of the Creative Commons Attribution License (CC BY). The use, distribution or reproduction in other forums is permitted, provided the original author(s) or licensor are credited and that the original publication in this journal is cited, in accordance with accepted academic practice. No use, distribution or reproduction is permitted which does not comply with these terms. 